\title{
The Effect of Water Parameters and Dissolved Minerals on the Hematological Parameters of during Breeding Period Catfish (Silurus glanis)
}

\author{
Azime Küçükgül ${ }^{1}$ \\ https://orcid.org/0000-0002-0515-6667 \\ Mücahit Yüngül ${ }^{2}$ \\ https://orcid.org/0000-0003-4226-0225 \\ Zuhal Kahraman ${ }^{3^{*}}$ \\ https://orcid.org/0000-0002-2499-7752 \\ Mustafa Dörücü ${ }^{1,2^{\star}}$ \\ https://orcid.org/0000-0002-1330-4965
}

${ }^{1}$ Munzur University, Fisheries Faculty, Department of Fish Disease, Tunceli, Turkey; ${ }^{2}$ Fırat Üniversity, Fisheries Faculty, Department of Fish Disease, 23119, Elazığ, Turkey; ${ }^{3}$ Fırat Üniversity, Fisheries Faculty, Department of Fish Breeding, 23119, Elazığ, Turkey

Received: 2018.07.30; Accepted: 2019.07.08.

*Correspondence author: akucukgul@munzur.edu.tr; Tel.: +90-428-2131794

\section{HIGHLIGHTS}

- In this research on Çelik Lake (Adıyaman, Turkey) the blood parameters of catfish (Silurus glanis Linnaeus, 1758) were evaluated.

- Blood sampling on before, during and after reproduction was performed by hematological analysis.

- Heamatolojical values during all time were affected by the water quality parameters.

Abstract: In this study, the blood parameters of catfish (Silurus glanis Linnaeus, 1758) inhabiting Çelik Lake (Adıyaman, Turkey) were investigated. The study was conducted between April 2013 and October 2013. After obtaining a blood sample from each catfish has been hematologically analyzed. Then, the water temperature, dissolved oxygen, $\mathrm{pH}$, calcium, magnesium and nitrate values were determined at before breeding (April), breeding period (June - July) and after breeding of fish (October) and the impacts of these data on hematological values were investigated. According to this study, it was observed that the 
hematological values obtained at before breeding period, breeding and after the breeding period were affected by the water quality parameters.

Keywords: Çelik Lake; hematological values; reproduction; water quality parameters.

\section{INTRODUCTION}

Various studies have been conducted for many years in the field of hematology of fish in our country and the world. The studies have been mostly dealing with erythrocyte and leukocyte count, hematocrit, leucocrit and hemoglobin levels. Especially to get good yields in the fish farms, it has become a necessity to investigate the fish in terms of biological, physiological, biochemical, histological and hematological in detail. The survey conducted on fish farming, identification of diseases and parasites in fish is an important issue. Therefore, one of the methods to be used for early detection of diseases has become a subject of concern of researchers in the fish hematology in recent years. For this purpose, comparative studies have carried out on blood samples taken from live fish or anesthetized fish [1-9].

In addition to interpret the hematological findings correctly in fish, it must be taken into account the physiological and biochemical effects of changes in negative environmental factors or pollution. In this context, hematological values in fish are alter with gender, reproductive period, sexual maturity, temperature, dissolved oxygen, $\mathrm{pH}$, some water quality parameters such as calcium, magnesium and nitrate, diseases and other environmental factors[10-14].

In this study, the effects of some water quality parameters such as water temperature, dissolved oxygen, $\mathrm{pH}$, calcium, and magnesium and nitrate values on the hematological values of the Silurus glanis caught from Çelik Lake during breeding periods were determined. Thus, in terms of the correct diagnosis of the factors causing the disease, minimize the disease and taking the necessary precautions, hematological findings can be used as prior knowledge in fisheries.

\section{MATERIAL AND METHODS}

Research was conducted between April 2013 and October 2013. Live catfish has been supplying from Çelik Lake in Gölbaşı Region of Adıyaman. Çelik Lake (37 $42^{\prime} 08.5^{\prime \prime} \mathrm{F}, 37^{\circ}$ 30' 08.9" D) is located $63 \mathrm{~km}$ away from Adiyaman and $17 \mathrm{~km}$ west of the Gölbaşı (Figure 1) which used for irrigation and fishing 15. The maximum depth of the lake, which is $2 \mathrm{~km}$ long, is $13.6 \mathrm{~m}$. Its surface area is $1.09 \mathrm{~km}^{2}$. Çelik Lake, which has a rich ecosystem, lives important fish including catfish (Silurus glanis) and carp (Cyprinus carpio) with high economic value [15]. Pinter nets are used when fishing. The measurements of these nets were measured with a steel meter with a length of 5 meters and the material thickness with a digital caliper. In order to determine hematological values of the fish at before breeding, breeding and after the breeding period, some previous references are used [15-19]. For this purpose a total of 51 adult fish were caught. Males (20 individuals) had a weight of 48.5-99 $\mathrm{cm}$ and weight of $710-6560 \mathrm{~g}$, while females (31 individuals) were $49.7-96.5 \mathrm{~cm}$ and $704-$ $5158 \mathrm{~g}$. 


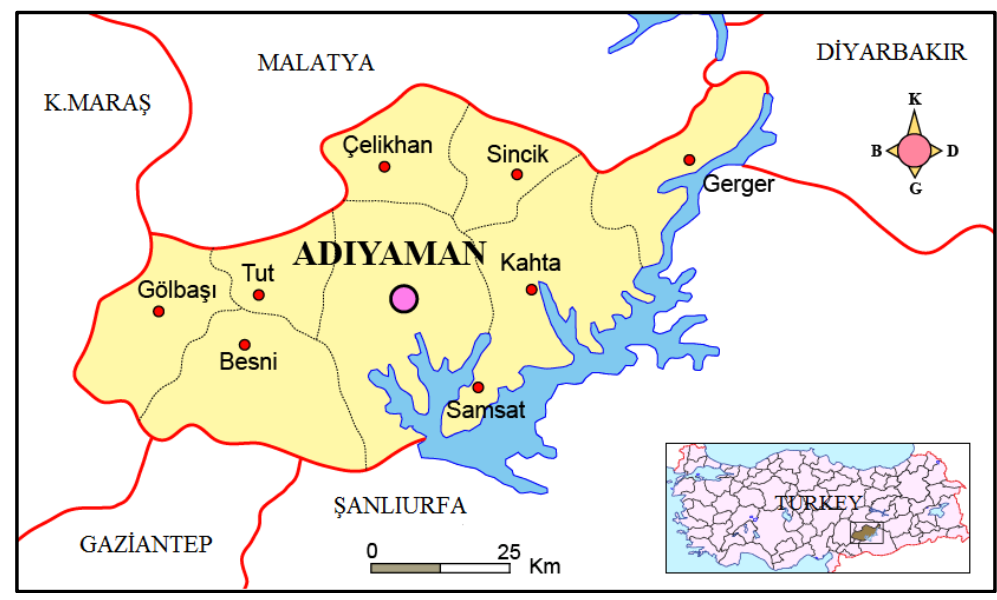

Figure 1. Geographical location of Çelik Lake [20]

Fish were anesthetized with benzocaine $(50 \mathrm{mg} / \mathrm{L})$ to obtain blood collection $[21,22]$. Fish were set up with a towel after anesthesia and taking the blood from the caudal vein with a sharp and fine-tipped syringe, then blood was filled into ethylene diamine tetra-acetic acid (EDTA) tubes [3]. In the counting of blood, thoma slides was used in erythrocyte and leukocyte counts. After determination of erythrocyte and leukocyte counts in $1 \mathrm{~mm} 3$ blood, they were examined in immersion lens in light microscope. Hematocrit and leucocrit values were detected with microhaematocrit method using centrifuge. For this, blood was taken into heparinized hematocrit capillary tubes. After centrifugation (12500 rpm 5 minutes), percentages calculated. Also, hemoglobin levels were determined by cyanomethemoglobin method using spectrophotometer [4, 23-26].

The gonads were macroscopically examined to confirm gender of the fish according to the terminology of [4].

The temperature, dissolved oxygen and $\mathrm{pH}$ levels of the lake water were measured before, during and after the breeding period of fish. According to this, oxygen meter with 0.01 sensitivity was used to determine water temperature and dissolved oxygen levels, and a $\mathrm{pH}$ meter of 0.003 sensitivity was used for determination of $\mathrm{pH}$. Calcium, magnesium and nitrate values were measured by ion exchange chromatography using the method specified by [27].

In this study, ANOVA multivariate Duncan's test was applied using the SPSS 17.0 package program for statistical evaluation of blood parameters between the reproductive periods. Student t-test was applied to statistical comparisons between blood parameters of female, male and all individuals at the same reproductive period. The results are expressed in "A, B, C". The relationship between hematological parameters in the blood samples of the catfish and the data obtained from some water quality values of the lake water depending on reproduction and gender was determined by Pearson's correlation coefficient [27].

\section{RESULTS}

Some blood parameter values (hematocrit and leucocrit values, erythrocyte and leucocyte counts, hemoglobin level) of the fish that are examined depending on breeding periods and gender are given in Table 1.

The level of hematocrit between consecutive reproductive periods for male, female and for all was significant $(p<0.05)$ (Table 1$)$. It was determined that the difference in hematocrit level between male and female individuals in the same reproductive period was statistically insignificant ( $p>0.05)$ (Table 1). It was determined that the leucocrit ratios of the female, male and all individuals in the same reproductive period were not statistically significant $(p>$ 0.05 ) but for pre- and reproductive period and post-reproductive period were significant ( $p$ $<0.05)$.

Erythrocyte counts between consecutive reproductive periods; between the reproductive period and the other periods for female, male and all individuals it was found to be insignificant $(p>0.05$ ) but between pre-reproduction period and post-reproductive 
period were insignificant $(p>0.05)$ (Table 1). The differences between erythrocyte counts of male, female and all individuals was found to be statistically insignificant ( $p>0.05)$ for preand reproductive period, but were insignificant for post reproductive period $(p<0.05)$ (Table 1).

Leucocyte counts among consecutive reproductive periods for female were not significant ( $p>0.05$ ) but was significant between breeding and other periods for male fish ( $p$ $<0.05)$. But insignificant between pre- and post-breeding period ( $p>0.05)$; between pre- and post-breeding period it was insignificant $(p<0.05)$ for all individuals (Table 1$)$. For all reproductive period, all individuals were statistically insignificant $(p>0.05)$.

Hemoglobin levels for female individuals at pre-reproductive and reproductive period were significant $(p<0.05)$, but no significant at post-reproductive period ( $p>0.05)$; for male fish between the all periods were no significant ( $p>0.05)$ (Table 1). The difference in hemoglobin amounts of female, male and all individuals at the same reproductive period was statistically insignificant $(p>0.05)$ (Table 1).

Table 1. Comparison of some blood parameter values of pre-breeding (PreB), breeding (B) and post-breeding (PostB) catfish species (mean \pm standard deviation)

\begin{tabular}{|c|c|c|c|c|c|c|}
\hline & & $\begin{array}{l}\text { Hematocrit } \\
\text { level (\%) }\end{array}$ & $\begin{array}{l}\text { Leukocrit } \\
\text { level (\%) }\end{array}$ & $\begin{array}{c}\text { Eritrocyte } \\
\text { count } \\
\left(\times 10^{6} / \mathrm{mm}^{3}\right) \\
\end{array}$ & $\begin{array}{c}\text { Leukocrit } \\
\text { count } \\
\left(\times 10^{4} / \mathrm{mm}^{3}\right)\end{array}$ & $\begin{array}{l}\text { Hemoglobin } \\
\text { value } \\
(\mathrm{g} / 100 \mathrm{ml}) \\
\end{array}$ \\
\hline \multirow{3}{*}{ 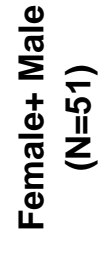 } & PreB & $33.47 \pm 2.55^{\mathrm{aA}}$ & $2.06 \pm 0.66^{\mathrm{aA}}$ & $1.35 \pm 0.05^{\mathrm{aA}}$ & $4.64 \pm 0.48^{\mathrm{aA}}$ & $6.34 \pm 0.68^{\mathrm{aA}}$ \\
\hline & B & $24.40 \pm 7.13^{\mathrm{bA}}$ & $2.60 \pm 0.91^{\mathrm{a}, \mathrm{bA}}$ & $1.23 \pm 0.12^{\mathrm{bA}}$ & $4.03 \pm 0.36^{\mathrm{bA}}$ & $5.97 \pm 0.84^{\mathrm{aA}}$ \\
\hline & $\begin{array}{l}\text { Post } \\
\text { B }\end{array}$ & $16.95 \pm 4.08^{\mathrm{cA}}$ & $2.95 \pm 0.97 \mathrm{bA}$ & $1.33 \pm 0.04^{\mathrm{aA}}$ & $4.38 \pm 0.27^{\mathrm{cA}}$ & $6.11 \pm 0.95^{\mathrm{aA}}$ \\
\hline \multirow{3}{*}{ 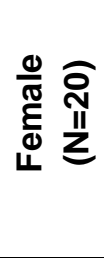 } & PreB & $33.86 \pm 2.85^{\mathrm{aA}}$ & $2.00 \pm 0.58^{\mathrm{aA}}$ & $1.36 \pm 0.05^{\mathrm{aA}}$ & $4.59 \pm 0.46^{\mathrm{aA}}$ & $6.43 \pm 0.40^{\mathrm{aA}}$ \\
\hline & B & $24.83 \pm 9.45^{\mathrm{bA}}$ & $2.83 \pm 0.75^{\mathrm{bA}}$ & $1.16 \pm 0.13^{\mathrm{bA}}$ & $4.17 \pm 0.31^{\mathrm{aA}}$ & $5.63 \pm 0.79^{\mathrm{bA}}$ \\
\hline & $\begin{array}{c}\text { Post } \\
\text { B }\end{array}$ & $16.29 \pm 3.59 \mathrm{cA}$ & $2.43 \pm 0.53^{\mathrm{a}, \mathrm{bB}}$ & $1.29 \pm 0.03^{\mathrm{aB}}$ & $4.27 \pm 0.22^{\mathrm{aA}}$ & $5.77 \pm 0.59^{\mathrm{a}, \mathrm{bA}}$ \\
\hline \multirow{3}{*}{$\frac{0}{\frac{\pi}{\pi}} \overline{\frac{\pi}{z}}$} & PreB & $33.20 \pm 2.44^{\mathrm{aA}}$ & $2.10 \pm 0.74^{\mathrm{aA}}$ & $1.34 \pm 0.04^{\mathrm{aA}}$ & $4.68 \pm 0.51^{\mathrm{aA}}$ & $6.27 \pm 0.83^{\mathrm{aA}}$ \\
\hline & B & $24.11 \pm 5.73^{\mathrm{bA}}$ & $2.44 \pm 1.01^{\mathrm{a}, \mathrm{bA}}$ & $1.28 \pm 0.09 \mathrm{bA}$ & $3.94 \pm 0.37^{\mathrm{bA}}$ & $6.19 \pm 0.84^{\mathrm{aA}}$ \\
\hline & $\begin{array}{l}\text { Post } \\
\text { B }\end{array}$ & $17.33 \pm 4.44^{\mathrm{cA}}$ & $3.25 \pm 1.06^{b C}$ & $1.35 \pm 0.03^{\mathrm{aC}}$ & $4.44 \pm 0.28^{\mathrm{aA}}$ & $6.31 \pm 1.09^{\mathrm{aA}}$ \\
\hline
\end{tabular}

$a, b, c$ : The same group in the column is no significant with the same letter $(P>0.05) ; A, B$ : Between consecutive gender groups are no significant with the same letter $(P>0.05)$.

Some water quality values of Çelik Lake are shown in Table 2. 
Table 2. Some water quality values of the lake water are cited.

\begin{tabular}{lrrc}
\hline Parameters & $\begin{array}{c}\text { Pre-reproductive } \\
\text { period (April) }\end{array}$ & $\begin{array}{c}\text { Reproduction } \\
\text { period (June) }\end{array}$ & $\begin{array}{c}\text { Post-reproductive } \\
\text { period (October) }\end{array}$ \\
\hline Temperature ( $(\mathbf{C})$ & 17.2 & 25 & 18.8 \\
Oxygen (mg/L) & 9.76 & 7.40 & 8.63 \\
pH & 7.65 & 8.32 & 7.95 \\
Calcium (mg/L) & 41.55 & 30.71 & 47.81 \\
Magnesium (mg/L) & 18.48 & 15.22 & 19.37 \\
Nitrate (mg/L) & 0.566 & 0.125 & 0.310 \\
\hline
\end{tabular}

The correlation coefficients ( $r$ ) determined in the correlation analysis between the data obtained from these water quality values and the hematological parameters of the cat fish are also given in Table 3 .

According to the statistical analysis between the water temperature and the hematological parameters of the catfish (S. glanis), there was no significant difference between temperature and hematocrit value, leukocyte count and hemoglobin amount for female fish $(p>0.05)$. On the other hand, the difference between temperature and leucocrit value $(p<0.05)$ and erythrocyte count was significant $(p<0.01)$. For male fish, there was no significant difference between temperature and haematocrit value, leucocrit value and hemoglobin level $(p>0.05)$. On the other hand, the difference between the temperature and the number of erythrocytes $(p<0.05)$ and leucocyte count was significant $(p<0.01)$. Statistical analysis showed that there was no significant difference $(p>0.05)$ between oxygen levels and the haematocrit value for female catfish.

There was no significant difference between the oxygen level and leucocrit value and hemoglobin amount for male fish ( $p>0.05)$. In contrast, the differences between the oxygen level and the haematocrit value $(p<0.01)$, the number of erythrocytes $(p<0.05)$ and the number of leucocytes were significant $(p<0.01)$.

Statistical analysis revealed that there was no significant difference between $\mathrm{pH}$ and hematocrit value for female fish ( $p>0.05$ ). In contrast, the difference between $\mathrm{pH}$ and leucocrit value $(p<0.05)$, erythrocyte count $(p<0.01)$, leucocyte count and hemoglobin amount was significant $(p<0.05)$. For male fish, there was no significant difference between $\mathrm{pH}$ and leucocrit value and hemoglobin level $(\mathrm{p}>0.05)$. In contrast, the difference between $\mathrm{pH}$ and haematocrit value $(\mathrm{p}<0.05)$, erythrocyte count $(\mathrm{p}<0.05)$ and leucocyte count was significant $(p<0.01)$. 
Table 3. Some water quality values of the lake water are cited.

\begin{tabular}{|c|c|c|c|c|c|c|c|}
\hline \multirow{2}{*}{$\begin{array}{l}\text { Water } \\
\text { quality } \\
\text { parameters }\end{array}$} & \multirow{2}{*}{ Gender } & \multirow{2}{*}{$\begin{array}{l}\text { Number } \\
\text { of } \\
\text { Sample }\end{array}$} & \multicolumn{5}{|c|}{ Hematological parameters } \\
\hline & & & $\begin{array}{l}\text { Hematocrit } \\
\text { value (\%) }\end{array}$ & $\begin{array}{l}\text { Leukocrit } \\
\text { value (\%) }\end{array}$ & $\begin{array}{c}\text { Eritrocyte } \\
\text { number } \\
\left(\times 10^{6} / \mathrm{mm}^{3}\right)\end{array}$ & $\begin{array}{c}\text { Leukocyte } \\
\text { number } \\
\left(\times 10^{4} / \mathrm{mm}^{3}\right)\end{array}$ & $\begin{array}{c}\text { Hemoglobin } \\
\text { amount } \\
(\mathrm{g} / 100 \mathrm{ml})\end{array}$ \\
\hline \multirow{2}{*}{$\begin{array}{l}\text { Temperature } \\
(\stackrel{\circ}{ })\end{array}$} & $\mathrm{F}$ & 20 & -0.177 & $0.474^{*}$ & $-0.751^{* *}$ & -0.392 & -0.405 \\
\hline & M & 31 & -0.202 & -0.024 & $-0.439^{*}$ & $-0.610^{* *}$ & -0.047 \\
\hline \multirow{2}{*}{$\begin{array}{l}\text { Oxygen } \\
\text { (mg/L) }\end{array}$} & $\mathrm{F}$ & 20 & 0.413 & $-0.505^{*}$ & $0.751^{\star *}$ & $0.461^{*}$ & $0.491^{*}$ \\
\hline & $M$ & 31 & $0.457^{\star *}$ & -0.133 & $0.371^{*}$ & $0.604^{* *}$ & 0.035 \\
\hline \multirow{2}{*}{ pH } & $\mathrm{F}$ & 20 & -0.387 & $0.504^{*}$ & $-0.755^{\star *}$ & $-0.455^{*}$ & $-0.484^{*}$ \\
\hline & $M$ & 31 & $-0.430^{*}$ & 0.115 & $-0.381^{*}$ & $-0.608^{* *}$ & -0.037 \\
\hline \multirow{2}{*}{$\begin{array}{l}\text { Calcium } \\
(\mathrm{mg} / \mathrm{L})\end{array}$} & $\mathrm{F}$ & 20 & -0.295 & -0.294 & $0.555^{*}$ & 0.167 & 0.143 \\
\hline & M & 31 & -0.296 & 0.291 & $0.440^{*}$ & $0.457^{\star *}$ & 0.055 \\
\hline \multirow{2}{*}{$\begin{array}{l}\text { Magnesium } \\
(\mathrm{mg} / \mathrm{L})\end{array}$} & $\mathrm{F}$ & 20 & -0.161 & -0.360 & $0.636^{* *}$ & 0.242 & 0.229 \\
\hline & $\mathrm{M}$ & 31 & -0.157 & 0.221 & $0.456^{\star *}$ & $0.520^{* *}$ & 0.054 \\
\hline \multirow{2}{*}{$\begin{array}{l}\text { Nitrate } \\
\text { (mg/L) }\end{array}$} & $\mathrm{F}$ & 20 & $0.493^{*}$ & $-0.504^{*}$ & $0.731^{* *}$ & $0.475^{*}$ & $0.512^{*}$ \\
\hline & M & 31 & $0.544^{* *}$ & -0.191 & 0.334 & $0.585^{* *}$ & 0.029 \\
\hline
\end{tabular}

Insignificant $(p>0,05)$, ${ }^{*}$ Significant $(p<0,05),{ }^{* *}$ Significant $(p<0,01)$, negative Correlation $(-)$, Female $(\mathrm{F})$, Male $(\mathrm{M})$

The statistical analysis of the relationship between the calcium values of Çelik Lake and the haematological parameters of the catfish revealed that there was not significant difference between the amount of calcium and haematocrit value, leucocrit value, leucocyte count and hemoglobin amount for female fish ( $p>0.05)$. In contrast, the difference between the amount of calcium and the number of erythrocytes was significant $(p<0.05)$. For male fish, there was no significant difference between the amount of calcium and haematocrit value, leucocrit level and hemoglobin level ( $p>0.05$ ). On the other hand, the difference between the amount of calcium and the number of erythrocytes $(p<0.05)$ and the number of leukocytes was significant $(p<0.01)$.

There was no significant difference between magnesium amount and hematocrit value, leukocrit value, leucocyte count and hemoglobin amount for female fish ( $p>0.05$ ) when the relationship between magnesium levels in water of Çelik Lake and haematological parameters of catfish were statistically analyzed. However, the difference between the amount of magnesium and the number of erythrocytes was significant $(p<0.01)$. For male fish, there was no significant difference ( $p>0.05)$ between magnesium amount and hematocrit value, leucocrit value and hemoglobin amount. In contrast, the difference between the amount of magnesium and the number of erythrocytes and leucocytes was significant $(p<0.01)$.

The difference between the nitrate amount and the number of erythrocytes haematocrit value, leucocrit value, leucocyte count and hemoglobin amount was found to be significant $(p<0.01)$. There was no significant difference between nitrate amount and leucocrit value, erythrocyte count and hemoglobin amount for male fish $(p<0.01)$. In contrast, the difference between nitrate amount and hematocrit value and leucocyte count was significant $(p<0.01)$.

\section{DISCUSSION}

In this study, pre-reproductive hematocrit values were determined as $33.47 \%$ for all individuals of (S. glanis), and this value was determined as $24.40 \%$ and $16.95 \%$ in reproductive period and post-reproductive period, respectively. Hematocrit values were 
found to be $29.75 \% 6,19.3 \%$ and $22.3 \% 3.4$ and $20 \% 8$. It is believed that the differences in haematocrit values in all three periods examined were due to differences in fish blood sampling periods. In this study, leucocrit levels were determined as $2.06 \%, 2.60 \%$ and $2.95 \%$ in reproductive period, pre-reproduction and post-reproductive period, respectively. Different blood parameters were previously investigated in studies on catfish, but no evidence of leucocrit was found. For this reason, leucocrit values in this study are thought to contribute to the work to be done later.

Kocabatmaz and Ekingen [3,4] determined the number of erythrocytes in $1.00 \times 106 /$ $\mathrm{mm}^{3}$ to $1.38 \times 106 / \mathrm{mm}^{3}$ and these values were $1.40 \times 106 / \mathrm{mm}^{3}$ in Docan [8]. In this study, it was determined that erythrocyte counts were $1.35 \times 106 / \mathrm{mm}^{3}$ for male and $1.33 \times 106 /$ $\mathrm{mm}^{3}$ for female fish before and after reproductive period respectively, and these values were similar to the studies of the mentioned above. However, the number of erythrocytes in the reproductive period was reported to be $1.23 \times 106 / \mathrm{mm}^{3}$. In this study, leucocyte counts of the pre-breeding, breeding and post-breeding period were determined as $4.64 \times 104 / \mathrm{mm}^{3}$, $4.03 \times 104 / \mathrm{mm}^{3}$, and $4.38 \times 104 / \mathrm{mm}^{3}$, respectively. Leucocyte counts were determined as $4.15 \times 104 / \mathrm{mm}^{3}$ [3], $4.60 \times 104 / \mathrm{mm}^{3}$ [4] and $17.0 \times 104 / \mathrm{mm}^{3}$ [6]. The leucocyte counts obtained in this study were in agreement with some of the above mentioned studies, and they were in contrast to some others. It is believed that the cause of these differences may be due to factors such as age and size of the fish, environmental conditions and physiological status of the fish.

Hemoglobin levels of pre-breeding, reproductive and post-breeding period were determined as $6.34 \mathrm{~g} / 100 \mathrm{ml}, 5.97 \mathrm{~g} / 100 \mathrm{ml}$ and $6.11 \mathrm{~g} / 100 \mathrm{ml}$, respectively. In a study carried out on catfish [4], the amount of hemoglobin was found to be $6.06 \mathrm{~g} / 100 \mathrm{ml}$, and this value correlated with the amount of hemoglobin in the breeding period in this study. In other studies, these values were determined as $7.0 \mathrm{~g} / 100 \mathrm{ml}$ [8] with $4.4 \mathrm{~g} / 100 \mathrm{ml}$ 3, 9.02 $\mathrm{g} / 100 \mathrm{ml}[6]$.

According to this study, when the water temperature is increased; hematocrit value, erythrocyte and leucocyte counts and hemoglobin levels decreased and leucocrit levels increased in pre-breeding and breeding periods. Leucocyte counts and hemoglobin levels increased and hematocrit and leucocrit values and erythrocyte counts decrease with decreasing water temperature after reproductive period. A decrease in hematocrit values (31.8\% and $43.5 \%)$, erythrocyte counts (0.964 and $1.318 \times 106 / \mathrm{mm} 3)$ and hemoglobin amounts $(1.36 \mathrm{~g} / 100 \mathrm{ml})$ were found to be related to the increase in water temperature before and during reproductive period. Hemoglobin values $(1.391 \times 106 / \mathrm{mm} 3)$ and hematocrit values (39.3\%) and erythrocyte counts $(1.191 \times 106 / \mathrm{mm} 3)$ decreased after the reproductive period [11]. Şahan and Cengizler [13] found that the amount of hemoglobin decreased $(6.39 \mathrm{~g} / 100 \mathrm{ml})$ due to the increase in water temperature and increased $(7.33 \mathrm{~g}$ $/ 100 \mathrm{ml})$ depending on the drop of the water. In another study, erythrocyte counts $(0.89 \mathrm{x}$ $106 / \mathrm{mm}^{3}$ ) and hematocrit values (42.60\%) decreased according to the water temperature decrease [14]. The findings obtained by all the researchers mentioned above comply with our findings. However, it has been emphasized in other researches that there is an increase in leukocyte counts with the increase of water temperature and there is no significant effect of water temperature on hematocrit values, hemoglobin amounts and erythrocyte counts $[29,30]$. In a study carried out by Joshi [5], hemoglobin levels $(8.18-10.95 \mathrm{~g} / 100 \mathrm{ml})$, erythrocyte counts $\left.\left(2.75-4.45 \times 106 / \mathrm{mm}^{3}\right) 100 \mathrm{ml}\right)$ and hematocrit values $(40.85 \%$ $44.27 \%$ ) increased with increasing water temperature in pre-breeding period (March-June), but observed no increase in erythrocyte counts and hematocrit values in breeding period (July-September). According to this result, there are differences between the research findings obtained by [5] and our findings. It is thought that these differences may be due to the size of the fish, habitat, fish species, breeding periods, seasons and other environmental conditions.

In this study, when the $\mathrm{pH}$ values increased; hematocrit values, erythrocyte and leucocyte counts and hemoglobin levels are decreased and leucocrit levels were increased in breeding and pre reproductive period. But after reproductive period leucocyte counts and hemoglobin levels increased with decreasing $\mathrm{pH}$ values and hematocrit and leucocrit values and erythrocyte counts decreased. In a study, hematocrit values (31.8 - 43.5\%), erythrocyte 
counts $\left(0.964-1.318 \times 106 / \mathrm{mm}^{3}\right)$ and hemoglobin levels $(1.36 \mathrm{~g} / 100 \mathrm{ml})$ decreased with increasing $\mathrm{pH}$ values in pre-reproductive and reproduction period. However hemoglobin amounts increased $(1.48 \mathrm{~g} / 100 \mathrm{ml})$ 11. It was determined that hematocrit values and erythrocyte counts in our study are opposite to other studies, depending on the increase or decrease of the $\mathrm{pH}$ values, and other findings are similar.

In another study, hematocrit values $(26.50-31.50)$, erythrocyte counts $(1.540-1.820 \times 106$ $\left./ \mathrm{mm}^{3}\right)$, leucocyte counts $\left(4.04-4.66 \times 104 / \mathrm{mm}^{3}\right)$ and hemoglobin amounts $(8.20-9.60 \mathrm{~g} /$ $100 \mathrm{ml}$ ) were found to be increased [7]. In addition, Cengizler and Şahan Azizoğlu [12] investigated some blood parameters in mirror carp living in Seyhan Dam Lake and reported that there was a decrease in erythrocyte $\left(1.322-2.997 \times 106 / \mathrm{mm}^{3}\right)$ and leukocyte $(13.385$ $-17.045 \times 106 / \mathrm{mm}^{3}$ ) counts with decreasing $\mathrm{pH}$. According to these results, there are differences between Örün et al. [7] and Cengizler and Şahan Azizoğlu [12] findings and our findings. All these differences are thought to be due to fish species, fish size, age difference and life of fish.

When the amount of oxygen decreased, hametological parameters decreased before and after reproductive period. After reproductive period decrease in hematocrit and leucocrit levels and increase in erythrocyte and leucocyte counts and hemoglobin levels were seen with increasing oxygen level. Docan et al. [8] showed a decrease in the amount of hemoglobin $(7.17 \mathrm{~g} / 100 \mathrm{ml})$ due to decreasing dissolved oxygen level and increase in hemoglobin amounts $(7.80 \mathrm{~g} / 100 \mathrm{ml})$ with increasing the amount of dissolved oxygen. Cengizler and Şahan Azizoğlu [12] reported a decrease in erythrocyte (1.322 - $2.997 \times 106$ $\left./ \mathrm{mm}^{3}\right)$ and leucocyte $(13.385-17.045 \times 106 / \mathrm{mm} 3)$ numbers with decreasing dissolved oxygen in Seyhan Dam Lake. Another study conducted by Şahan and Cengizler [13], both of hemoglobin $(6.39 \mathrm{~g} / 100 \mathrm{ml})$ and leucocyte counts $\left(2.54 \times 104 / \mathrm{mm}^{3}\right)$ decreased due to the decrease of the dissolved oxygen amount. In addition to, the authors showed that there were an increase in erythrocyte counts $\left(2.61 \times 106 / \mathrm{mm}^{3}\right)$ and hemoglobin amounts $(7.13 \mathrm{~g}$ / $100 \mathrm{ml}$ ) and a decrease in hematocrit values (47.42\%) due to the increase in the amount of dissolved oxygen. The findings obtained by all of the above researchers are in accordance with our findings.

In this study, leucocrit levels increased but erythrocyte counts, hematocrit values, leukocyte counts and hemoglobin levels decreased when calcium, magnesium and nitrate values decreased before and during reproductive period. Decrease in hematocrit and leucocrit with increasing the calcium, magnesium and nitrate levels after the reproductive period; and increase in erythrocyte, leucocyte counts and hemoglobin levels were observed [28]. In another study, a decrease in hematocrit values (31.8 - 43.5\%), erythrocyte counts $\left(0.964-1.318 \times 106 / \mathrm{mm}^{3}\right)$ and hemoglobin amounts $(1.36 \mathrm{~g} / 100 \mathrm{ml})$ were determined according to the decrease in calcium levels before and during the reproductive period and an increase in hemoglobin levels $(1.48 \mathrm{~g} / 100 \mathrm{ml})$ and hematocrit values $(39.3 \%)$ and erythrocyte counts $\left(1.191 \times 106 / \mathrm{mm}^{3}\right)$ with increasing calcium levels were reported after the reproductive period [11]. Örün et al. [7] and Jerônimo et al. [29] reported that an increase in hemoglobin levels $(8.20-9.60 \mathrm{~g} / 100 \mathrm{ml})$, erythrocyte $\left(1.540-1.820 \times 106 / \mathrm{mm}^{3}\right)$ and leucocyte counts $\left(4.04-4.66 \times 10^{4} / 100 \mathrm{ml}\right)$ and hematocrit values $(26.50 \%-31.50 \%)$ occurred with increasing calcium values. The findings of the researchers mentioned above are parallel to our findings.

\section{CONCLUSION}

As a result; it was determined that blood parameter values of $S$. glanis were influenced by some water quality parameters such as water temperature, dissolved oxygen amount, $\mathrm{pH}$, calcium, magnesium and nitrate values. In evaluating the blood parameters, it is also necessary to consider the age and size of the fish, breeding periods, gender, seasons, physiology of the fish, habitat and environmental conditions. Catfish is an economically important species in inland waters and hematological studies on this species are expected to shed light on biological, ecological and parasitological studies to be carried out later on for other species to be cultivated. 


\section{REFERENCES}

1. Ezzat A, Shabana M, Farghaly A. Studies on thebloodcharactenstics of Tilapia zilli (Gervais) I. blood cells. J Fish Biol. 1974; 6:1-12.

2. Denton JE, Youset MK. Seasonal changes in hematology of rainbow trout, Salmo gairdneri. Comp Biochem Physiol A Mol. 1974; 51:151-3.

3. Kocabatmaz M, Ekingen G. Beş tatlısu balığı türünde bazı hematolojik normlar üzerine ön çalışmalar. Fırat Üniv Vet Fak Derg. 1977; 4:223-32.

4. Kocabatmaz M, Ekingen G. Değişik tür balıklarda kan örneği alınması ve hematolojik metodların standardizasyonu. Elazığ: Türkiye Bilimsel ve Teknik Araştırma Kurumu Veterinerlik ve Hayvancılık Araştırma Grubu Proje No: VHAG-557; 1982. 72 p.

5. Joshi PC. Seasonalchanges in thebloodparameters of a hill-streamteleost, Channagachua. Comp Physiol Ecol. 1989;14(2):71-3.

6. Aydın F, Yıldız Yavuzcan H, Pülatsü S. Sağlıklı yayın balıkları (Silurus glanis) ve karabalıklarda (Clarias lazera) bazı hematolojik parametreler üzerine bir çalışma. Ankara Üniv Vet Bilim Derg. 1998;14(1):51-3.

7. Örün İ. Karakaya Baraj Gölü'nde Yaşayan ve Ekonomik Öneme Sahip Bazı Balıkların [Acanthobrama marmid (Heckel 1843), Leuciscus cephalus orientalis (Nordmann 1840), Chondrostoma regium (Heckel 1843), Capoeta trutta (Heckel 1843) ve Capoeta capoeta umbla (Heckel 1843)] Hematolojik Yönden İncelenmesi, Doktora Tezi (unpublished), İ.Ü Fen Bilimleri Enstitüsü, Malatya; 2000.

8. Docan A, Cristea V, Grecu I, Dediu L. Haematological response of the European cat fish, Silurus glanis reared at different densities in "flow-through" production system. Archiva Zootechnica. 2010;13(2):63-70.

9. Yüngül M, Özdemir Y. Çelik Gölü (Adıyaman, Türkiye)'ndeki yayın (Silurus glanis Linnaeus, 1758) balığının hematolojik parametreleri üzerine üremenin etkisi. İstanbul Üniv Su Ürün Derg. 2014;29(1):48-59.

10. Christensen GM, Frandt JT, Poeschl BA. Cells, Proteins and certain physical chemical properties of brook trout (Salvelinus fontinalis) blood. J Fish Biol. 1980; 12:51-60.

11. Hardig J, Höglund LB. Seasonal variation in blood components of reared baltic salmon, Salmo salar L. J Fish Biol. 1984;24:565-79.

12. Cengizler İ, Şahan Azizoğlu A. Seyhan Baraj Gölü ve Seyhan Nehrin'de yaşayan aynalı sazan (Cyprinus carpio, Linnaeus, 1758)'larda bazı kan parametrelerinin belirlenmesi. Turk J Vet Anim Sci. 2000; 24:205-14.

13. Şahan A, Cengizler İ. Seyhan Nehri (Adana Kent İçi Bölgesi)'nde yaşayan benekli siraz (Capoeta barroisi Lortet, 1894) ve kızılgöz (Rutilus rutilus Linnaeus, 1758)'de hematolojik parametrelerin belirlenmesi. Turk J Vet Anim Sci. 2002; 26:849-58.

14. Aras M, Bayır A, Sirkecioglu AN, Polat H, Bayır M. 2008. Seasonal variations in serum lipids, lipoproteins and some haematological parameters of chub (Leuciscus cephalus). Italy J Anim Sci. 2008; 7:439-48.

15. Anonim. Gölbaşı Gölleri Uzun Devreli Gelişme Planı İçin Altık Rapor, T.C Çevre Orman Bakanlığı Doğa Koruma ve Milli Parklar Genel Müdürlüğü, Ankara; 2009. 151 p.

16. Smith PW. The fishes of Illinois. University of Illinois Press, Urbana, 1979.

17. Çelikkale, M.S. İçsu Balıkları ve Yetiştiriciliği, Karadeniz Teknik Üniversitesi Sürmene Deniz Bilimleri Fakültesi 124/ I, Trabzon; 2002. 419 s.

18. URL 1, 2016. http://cografyaharita.com/turkiye mulki idare haritalari.html

19. Summerfelt RC, Smith LS. Anesthesia, surgery and related techniques. In Methods for Fishery Biology; Schreck, C.B., Moyle, P.B., Eds.; Bethesda, Maryland: American Fisheries Society; 1990. pp. 213-272.

20. Ross LG, Ross B. Anesthetic and Sedative Techniques for Fish, Oxford: Blacwell Publishing Ltd; 1999. $176 \mathrm{p}$.

21. Konuk T. Pratik Fizyoloji, Ankara Üniversitesi Veteriner Fakültesi Yayınları, Ankara Üniversitesi Basımevi, Ankara, 1981; $250 \mathrm{~s}$.

22. İmren AH, Turan O. Klinik Tanıda Laboratuar (Metotlar, Bulguların Değerlendirilmesi, Fonksiyon Testleri), Beta Basım Yayın Dağıtım; 1985. 845 s. 
23. Siwicki AK, Anderson DP. Immunostimulation in fish: Measuring theeffects of stimulants by serological and immunological methods. Sweden: Symposium on Fishlmmunology Lysekil; 1993. $24 \mathrm{p}$.

24. Aktümsek A, Zengin G. Fizyoloji Laboratuarı, Nobel Bilim ve Araştırma Merkezi Yayın No:72, Ankara; $2011.124 \mathrm{~s}$.

25. AOAC. Official Methods of Analysis of the Association of Official Analytical Chemists, 18th Edition, Maryland; 2005.

26. Kalaycı Ş. SPSS Uygulamalı Çok Değişkenli İstatistik Teknikleri, Asil Yayın Dağıtım Ltd. Şti., Ankara; 2010. $426 \mathrm{~s}$.

27. Aslan A. Çanakkale Boğazı'ndaki izmarit balığı (SpicaramaenaLinnaeus, 1758)'nın bazı hematolojik ve biyokimyasal kan parametrelerinin belirlenmesi, Yüksek Lisans Tezi, ÇOMÜ Fen Bilimleri Enstitüsü, Çanakkale; 2009.

28. Çelik AŞ, Kaya H, Yılmaz S, Çakıcı H. Karagöz istavrit (Trachurus trachurus) balığının hematolojik parametrelerine su sıcaklığı, tuzluluk, mevsim, üreme, cinsiyet, balık büyüklüğü ve yaşın etkisi. Kafkas Üniv Vet Fak Derg. 2012;18(4):551-8.

29. Jerônimo GT, Brum A, Benites de Pádua S, Gonçalves ELT, Capecci RS, Ishikawa MM, Martins ML. Haematological Parameters of the Hybrid Surubim (Pseudoplatystoma reticulatum $\times$ P. corruscans) farmed in Brazil. Braz Arch Biol Technol. 2015;58(2):254-61. 